International Journal of

Descriptive and

Experimental Psychopathology,

Phenomenology and

Psychiatric Diagnosis

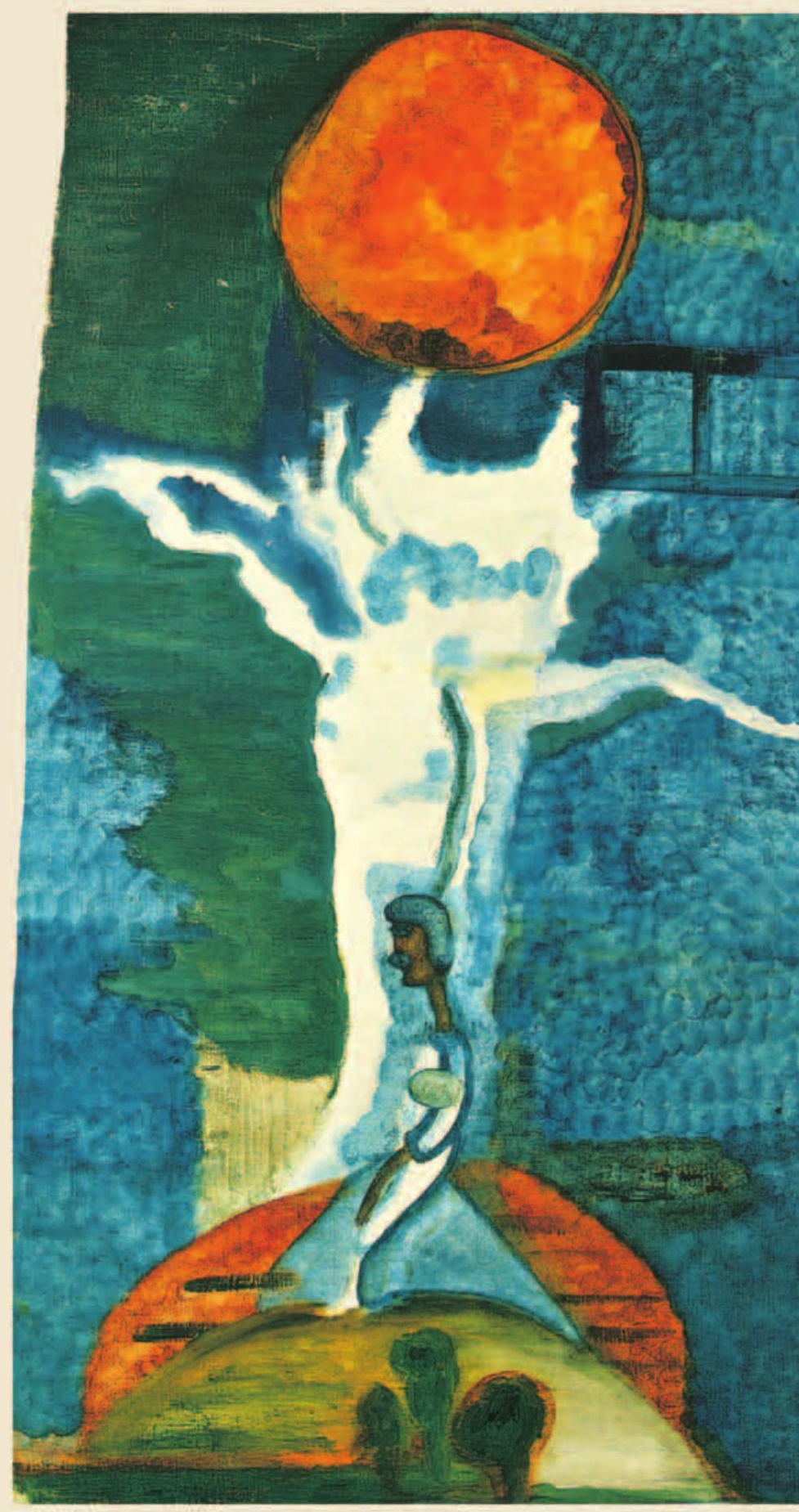




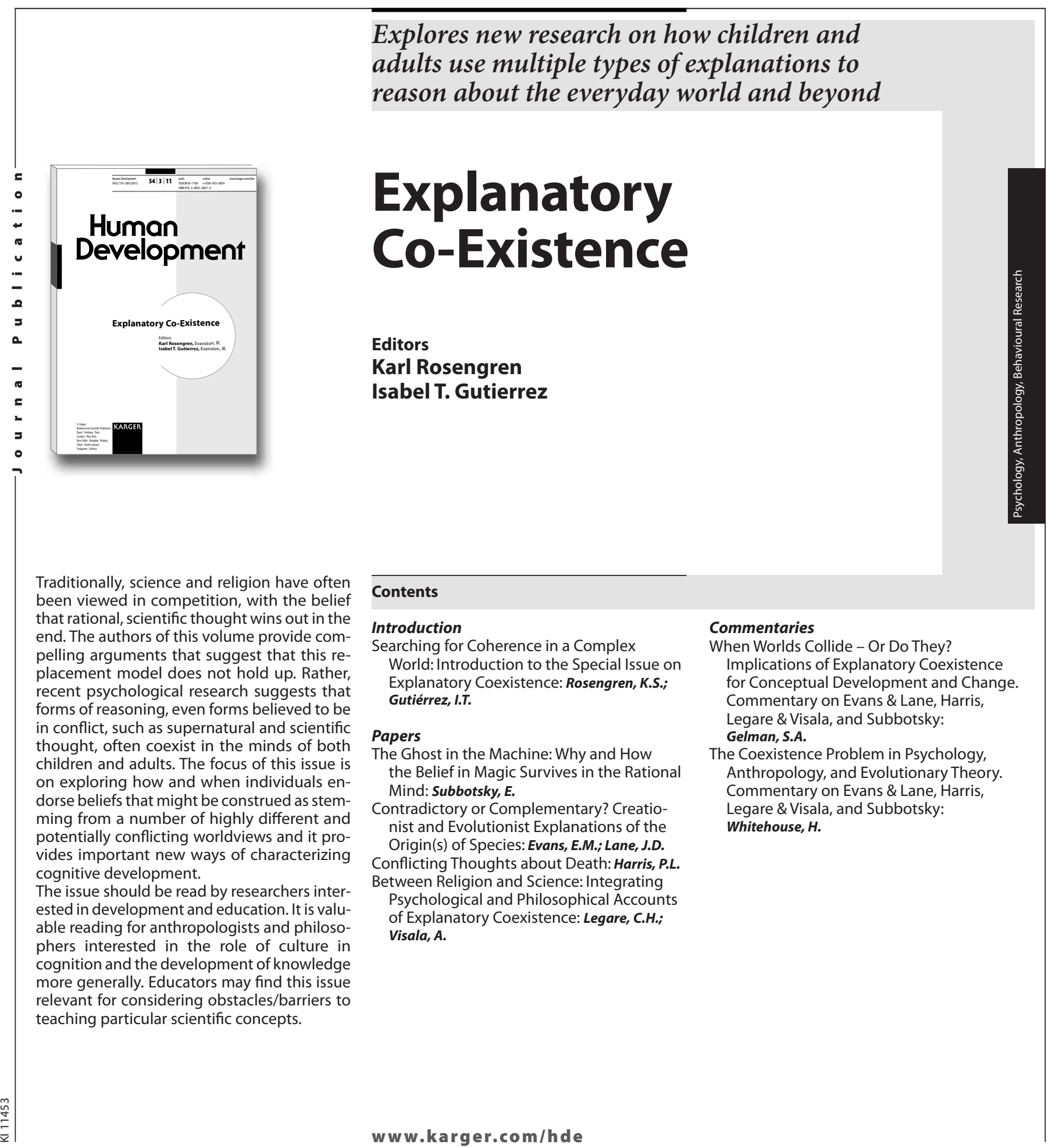

Traditionally, science and religion have often been viewed in competition, with the belief recent psychological research suggests that forms of reasoning, even forms believed to be conflict, such as supernatural and scientific . vides important new ways of characterizing cognitive development.

sted in develop able reading for anthropologists and philosophers interested in the role of culture in cognition and the development of knowledge more generally. Educators may find this issue relevant for considering obstacles/barriers to www.karger.com/hde

Explanatory Co-Existence

Editors: Rosengren, K. (Evanston, III.); Gutierrez, I.T.

(Evanston, III.)

82 p., 5 fig., 1 tab., soft cover, 2011

CHF 39.- / EUR 33.- / USD 46.00

Prices subject to change

EUR price for Germany, USD price for USA only

ISBN 978-3-8055-9827-9

e-ISBN 978-3-8055-9828-6

Special Topic Issue:

Human Development

Vol. 54, No. 3 (2011)

Included in subscription

KARGER
Please send: __ copy/ies

Postage and handling free with prepayment

$\boldsymbol{\varepsilon}$

Payment:

Please charge to my credit card

- $\square$ American Express $\square$ Diners $\quad \square$ Eurocard

ᄂ $\square$ MasterCard

Card No.:

Exp. date:

CVV/CVC

(3 digits in the signature field on the back of Visa and MasterCard)

$\square$ Check enclosed $\quad \square$ Please bill me

Orders may be placed with any bookshop, subscription agency, directly with the publisher or through a Karger distributor.
Fax: +41613061234

S. Karger AG, P.O. Box, CH-4009 Basel (Switzerland)

E-Mail orders@karger.ch,www.karger.com

Name/Address:

Date: 


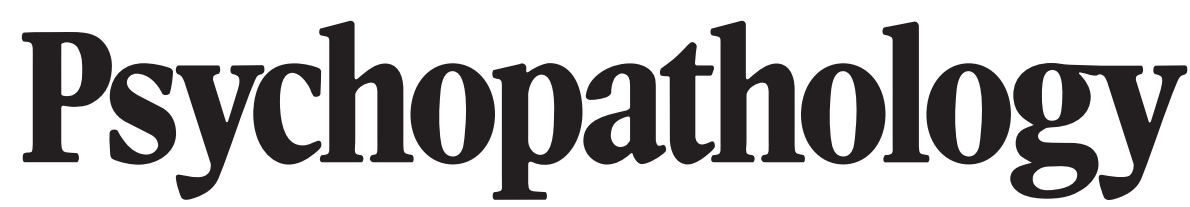

International Journal of Descriptive and Experimental Psychopathology, Phenomenology and Psychiatric Diagnosis

Founded 1897 as 'Monatsschrift für Psychiatrie und Neurologie', continued 1957-1967 as 'Psychiatria et Neurologia', continued $1968-1983$ as 'Psychiatria Clinica'

Founders: C. Wernicke and Th. Ziehen

Successors: K. Bonhoeffer (1912-1938), J. Klaesi (1939-1967), E. Grünthal (1953-1973),

N. Petrilowitsch (1968-1970), Th. Spoerri (1971-1973), P. Berner (1974-1999),

E. Gabriel (1974-2004), Ch. Mundt (2005-2011)

\section{Editor-in-Chief}

S.C. Herpertz, Heidelberg

\section{Honorary Consultant Editor}

H.S. Akiskal, San Diego, Calif.

\section{Editorial Assistant}

S. Neidlein, Heidelberg

\section{Section Editors}

T. Fuchs, Heidelberg

V. Gallese, Parma

S.C. Herpertz, Heidelberg

P. McGorry, Melbourne, Vic.

\section{Editorial Board}

A. Arntz, Maastricht

D. Bhugra, London

A. Buchheim, Innsbruck

F. Caspar, Bern

A.M. Chanen, Parkville, Vic.

Y.-F. Chen, Beijing

A.S. David, London

N.M.J. Edelstyn, Keele

H. Fabisch, Graz

K. Fabisch, Graz

P. Falkai, Göttingen

H.J. Freyberger, Greifswald/ Stralsund

S.N. Ghaemi, Boston, Mass.

J.G. Gunderson, Belmont, Mass.

M. Härter, Hamburg

A. Heerlein, Santiago

P. Henningsen, München

H.P. Kapfhammer, Graz

J. Klosterkötter, Köln

M.F. Lenzenweger,

Binghamton, N.Y.

S. Löber, Heidelberg

W. Maier, Bonn

M. Maj, Naples

Ch. Mundt, Heidelberg

J. Parnas, Copenhagen
C. Reck, Heidelberg

F. Resch, Heidelberg

F. Schneider, Aachen

K. Schnell, Heidelberg

L. Siever, New York, N.Y.

K. Silk, Ann Arbor, Mich.

C. Sinigaglia, Milan

G. Stanghellini, Florence

E. Vieta, Barcelona

M. Weisbrod, Karlsbad

A.R. Yung, Parkville, Vic.
Printed in Switzerland on acid-free and non-aging paper (ISO 9706) by

Reinhardt Druck, Base
Appears bimonthly: 1 volume per year (6 issues) 


\section{Psychopathology}

'Psychopathology' addresses scientists who work on descriptive psychopathology in clinical contexts, or with experimental methods in neuropsychology and experimental psychopathology, or on conceptual framing of psychopathological findings for understanding pathogenesis and for validation of diagnosis and classification. They may include an interdisciplinary approach to other medical and biological fields or to the humanities. Psychopathology does not only invite reports on medical research but also wants to address psychologists who refer to pathological phenomena or work within clinical settings. The central field of interest is the convergence of clinical phenomena, experimental findings, and conceptualisation. This would also include describing pathogenetic mechanisms of disturbed neuropsychological functions which allows remodelling and evaluation of psychotherapeutic tools.

'Psychopathology' accepts papers on the four following sections: Original Paper, Review, Case Report, Letter to the Editor. Reviews may contain overviews, meta-analyses and conceptual papers based on a literature overview; Original Papers contain data generated by the authors; Case Reports will only be accepted if they stimulate novel functional insights or classificatory concepts; Letters to the Editor will also be restricted to relevant issues of scientific debate.

\section{Submission}

Only original papers written in English are considered and should be submitted using the online submission website at:

$$
\text { www.karger.com/psp }
$$

Should you experience any problems with your submission, please contact:

Shirin.Neidlein@med.uni-heidelberg.de
Editorial Office 'Psychopathology'
Zentrum für Psychosoziale Medizin
Klinik für Allgemeine Psychiatrie
Universität Heidelberg
Voßstr. 4
D-69115 Heidelberg
Tel. +49 6221567308
Fax +49 6221565477

\section{Conditions}

All manuscripts are subject to editorial review. Manuscripts are received with the explicit understanding that they are not under simultaneous consideration by any other publication. Submission of an article for publication implies the transfer of the copyright from the author to the publisher upon acceptance. Accepted papers become the permanent property of 'Psychopathology' and may not be reproduced by any means, in whole or in part, without the written consent of the publisher. It is the author's responsibility to obtain permission to reproduce illustrations, tables, etc. from other publications.

\section{Arrangement}

Title page: The first page of each paper should indicate the title, the authors' names, the institute where the work was conducted, and a short title for use as running head.

Full address: The exact postal address of the corresponding author complete with postal code must be given at the bottom of the title page. Please also supply phone and fax numbers, as well as e-mail address.

Key words: Please supply 3-10 key words in English that reflect the content of the paper.

Abstract: The abstract should not exceed 30 lines and should be structured as follows: Background, Sampling and Methods, Results, and Conclusions (including study limitations)

Methods: Sampling should be described in detail so that possible selection biases may be discussed. Methods should be reported in a manner enabling easy replication.
Results: The results should be described precisely and must be separated from the discussion.

Discussion: The discussion should move along the same lines as the results and should discuss the relevant literature with regard to consistencies and inconsistencies as well as elucidate on the theoretical and practical implications of the results. Further research perspectives may be addressed, e.g. concerning clarification of inconsistencies with the literature.

Footnotes: Avoid footnotes. When essential, they are numbered consecutively and typed at the foot of the appropriate page.

Tables and illustrations: Tables and illustrations (both numbered in Arabic numerals) should be prepared on separate sheets. Tables require a heading and figures a legend, also prepared on a separate sheet. For the reproduction of illustrations, only good drawings and original photographs can be accepted; negatives or photocopies cannot be used. Due to technical reasons, figures with a screen background should not be submitted. When possible, group several illustrations on one block for reproduction (max. size $180 \times 223 \mathrm{~mm}$ ) or provide crop marks. Electronically submitted b/w half-tone and color illustrations must have a final resolution of $300 \mathrm{dpi}$ after scaling, line drawings one of 800-1200 dpi.

Color illustrations

Online edition: Color illustrations are reproduced free of charge. In the print version, the illustrations are reproduced in black and white. Please avoid referring to the colors in the text and figure legends.

Print edition: Up to 6 color illustrations per page can be integrated within the text at CHF 800.- per page.

References: In the text, identify references by Arabic numerals [in square brackets]. Material submitted for publication but not yet accepted should be noted as 'unpublished data' and not be included in the reference list. The list of references should include only those publications which are cited in the text. Do not alphabetize; number references in the order in which they are first mentioned in the text. The surnames of the authors followed by initials should be given. There should be no punctuation other than a comma to separate the authors. Preferably, please cite all authors. Abbreviate journal names according to the Index Medicus system. Also see International Committee of Medical Journal Editors: Uniform requirements for manuscripts submitted to biomedical journals (www.icmje.org).

Examples

(a) Papers published in periodicals: Sun J, Koto H, Chung KF: Interaction of ozone and allergen challenges on bronchial responsiveness and inflammation in sensitised guinea pigs. Int Arch Allergy Immunol 1997;112:191-195.

(b) Papers published only with DOI numbers:

Theoharides TC, Boucher W, Spear K: Serum interleukin-6 reflects disease severity and osteoporosis in mastocytosis patients. Int Arch Allergy Immunol DOI: 10.1159/000063858. (c) Monographs: Matthews DE, Farewell VT: Using and Understanding Medical Statistics, ed 3, revised. Basel, Karger, 1996

(d) Edited books: Parren PWHI, Burton DR: Antibodies against HIV-1 from phage display libraries: Mapping of an immune response and progress towards antiviral immunotherapy; in Capra JD (ed): Antibody Engineering. Chem Immunol. Basel, Karger, 1997, vol 65, pp 18-56.

Reference Management Software: Use of EndNote is recommended for easy management and formatting of citations and reference lists.

\section{Digital Object Identifier (DOI)}

S. Karger Publishers supports DOIs as unique identifiers for articles. A DOI number will be printed on the title page of each article. DOIs can be useful in the future for identify- ing and citing articles published online without volume or issue information. More information can be found at www. doi.org

\section{Supplementary Material}

Supplementary material is restricted to additional data that are not necessary for the scientific integrity and conclusion of the paper. Please note that all supplementary files will undergo editorial review and should be submitted together with the original manuscript. The Editors reserve the right to limit the scope and length of the supplementary material. Supplementary material must meet production quality standards for Web publication without the need for any modification or editing. In general, supplementary files should not exceed $10 \mathrm{MB}$ in size. All figures and tables should have titles and legends and all files should be supplied separately and named clearly. Acceptable files and formats are: Word or PDF files, Excel spreadsheets (only if the data cannot be converted properly to a PDF file), and video files (.mov, avi mpeg).

\section{Author's Choice ${ }^{\mathrm{TM}}$}

With this option the author can choose to make his article freely available online against a one-time fee of CHF 3000.This fee is independent of any standard charges for supplementary pages, color images etc. which may apply. More information can be found at www.karger.com/authors_choice.

\section{NIH-Funded Research}

The U.S. National Institutes of Health (NIH) mandates under the NIH Public Access Policy that final, peer-reviewed manuscripts appear in its digital database within 12 months of the official publication date. As a service to authors, Karger submits the final version of your article on your behalf to PubMed Central (PMC) immediately upon publishing. It usually receives a PMCID within approximately a month and will appear in PMC after 12 months. For those selecting our premium Author's Choice ${ }^{\mathrm{TM}}$ service, the usual embargo will be overriden, accelerating the accessibility of your work. More details on NIH's Public Access Policy are available at http://publicaccess.nih.gov/policy.htm

\section{Self-Archiving}

Karger permits authors to archive their pre-prints (i.e. prerefereeing) or post-prints (i.e. final draft post-refereeing) on their personal or institution's servers, provided the following conditions are met: Articles may not be used for commercial purposes, must be linked to the publisher's version, and must acknowledge the publisher's copyright. Authors selecting Karger's Author's Choice ${ }^{\mathrm{TM}}$ feature, however, are also permitted to archive the final, published version of their article, which includes copyediting and design improvements as well as citation links.

\section{Page Charges}

There is no page charge for papers of 5 or fewer printed pages (including tables, illustrations and references). Each additional complete or partial page is charged to the author at CHF 325.-. The allotted size of a paper is equal to approx. 14 manuscript pages (including tables, illustrations and references).

\section{Proofs}

Unless indicated otherwise, proofs are sent to the corresponding author and should be returned with the least possible delay. Alterations other than the correction of printer's errors are charged to the author.

\section{Reprints}

Order forms and a price list are sent with the proofs. Orders submitted after the issue is printed are subject to considerably higher prices.

\section{KARGER}

Fax +41613061234 E-Mail karger@karger.ch www.karger.com 


\section{Psychopathology}

ISSN Print Edition: 0254-4962

ISSN Online Edition: 1423-033X

Journal Homepage: www.karger.com/psp

Publication Data: 'Psychopathology' is published 6 times a year. Volume 45 with 6 issues appears in 2012 .

Copyright: () 2012 S. Karger AG, Basel (Switzerland). All rights reserved. No part of this publication may be translated into other languages, reproduced or utilized in any form or by any means, electronic or mechanical, including photocopying, recording, microcopying, or by any information storage and retrieval system, without permission in writing from the publisher or, in the case of photocopying, direct payment of a specified fee to the Copyright Clearance Center.

Disclaimer: The statements, opinions and data contained in this publication are solely those of the individual authors and contributors and not of the publisher and the editor(s). The appearance of advertisements in the journal is not a warranty, endorsement, or approval of the products or services advertised or of their effectiveness, quality or safety. The publisher and the editor(s) disclaim responsibility for any injury to persons or property resulting from any ideas, methods, instructions or products referred to in the content or advertisements.
Subscription Rates: Subscriptions run for a full calendar year. Prices are given per year. Personal subscription:

Print or Online

CHF 230.-

EUR 184-

USD 223.00

Print+Online combined CHF 278.-

EUR 222.-

USD 270.00

postage and handling (added to print and print+online)

CHF 40.80 Europe, CHF 60.00 Overseas

EUR 31.20

USD 56.40

Institutional subscription

Print or Online

Print+Online combined

CHF 1685.

EUR 1348.-

CHF 1854.-

USD 1636.00

postage and handling (added to print and print+online)

CHF 51.00 Europe, CHF 75.00 Overseas

EUR 39.00

USD 70.50

Airmail surcharge: CHF 51.- / USD 48.00

Discount subscription prices: Various related societies.
Back Volumes and Single Issues: Information on availability and prices of single print issues and print or electronic back volumes can be obtained from Customer Service at service@karger.ch.

Bibliographic Indices: This journal is regularly listed in bibliographic services, including Current Contents and PubMed/MEDLINE.

Photocopying: This journal has been registered with the Copyright Clearance Center (CCC), as indicated by the code appearing on the first page of each article. For readers in the US, this code signals consent for copying of articles for personal or internal use, or for the personal or internal use of specific clients, provided that the stated fee is paid per copy directly to

Copyright Clearance Center Inc.

222 Rosewood Drive

Danvers, MA 01923 (USA)

A copy of the first page of the article must accompany payment. Consent does not extend to copying for general distribution, for promotion, for creating new works, or for resale. In these cases, specific written permission must be obtained from the copyright owner,

S. Karger AG, P.O. Box

CH-4009 Basel (Switzerland).
Subscription Orders:

Orders can be placed at agencies, bookstores, directly with the Publisher

\section{S. Karger AG}

Medical and Scientific Publishers

P.O. Box

CH-4009 Basel

Switzerland

(for courier services only:

Allschwilerstrasse 10

CH-4055 Basel)

t: +41613061111

f: +41613061234

e: karger@karger.ch

w: www.karger.com or further Karger offices

or representatives:

Germany

S. Karger GmbH
Postfach

79095 Freiburg

Deutschland

(Hausadresse: Wilhelmstrasse 20A,

79098 Freiburg)

t: +49761452070

f: +497614520714

e: information@karger.de

w: www.karger.de

Japan

Karger Japan, Inc.

Shiba Daimon Asahi Bldg. 2F

1-2-23 Shiba Daimon

Minato-ku

Tokyo 105-0012

Japan

t: +81364356242

f: +81364356244

e: publisher@karger.jp

w: www.karger.jp

Change of Address:

Both old and new address should be sent

Both old and new address sho subscription source.
to the sula

USA

S. Karger Publishers, Inc.

26 West Avon Road

P.O. Box 529

Unionville, CT 06085

USA

Toll free: +1 8008285479

t: +18606757834

f: +18606757302

e: karger@snet.net

France

Librairie Médi-Sciences Sar

36, bd de Latour-Maubourg

75007 Paris

France

$\mathrm{t}: \quad+33(0) 145514258$

f: $+33(0) 145560780$

e: librairie@medi-sciences.f

w: librairie@medi-sciencedi-sciences.fr

Gulf Council Countries, Iran,

Middle East, North Africa, Turkey

Trans Middle East International

Distribution Co. Ltd.

KaSha

134 Queen Rania Al Abdullah Street

Jordan Trade Center Bldg. 3rd Floor

P.O. Box 2376

Amman 11953

Jordan

t: +96265153467

f: +96265153472

e: info@kasha.cc

w: www.KaShaonline.com
South East Asia, China and Taiwan Karger Regional Office (Malaysia)

CEO Suite Kuala Lumpur

Quill 7, 27th Floor

Jalan Stesen Sentral 5

KL Sentral

Kuala Lumpur 50470

Malaysia

t: +60327766803

f: +60327766999

e: service@karger.cn; r.chew@karger.cn

\section{Karger China}

10th Floor, Twin Towers (East)

B12 Jianguomenwai Avenue

Beijing 100022

China

t: +861051235033

f: +861051235122

e: service@karger.cn; r.chew@karger.cn

w: www.karger.cn

India, Bangladesh, Sri Lanka

Medscience India

Plot No. 17, Yusuf Sarai Market

B.L. Glass Building, 2nd Floor

Sri Aurobindo Marg

New Delhi 110016

India

t: +911146029633

f: +911146029634

c: +919891052128

e: medsci.india@gmail.com

\section{KARGER}

Fax +41 613061234

E-Mail karger@karger.ch

www.karger.com
(C) 2012 S. Karger AG, Basel

The Journal Home Page is available at:

www.karger.com/psp 


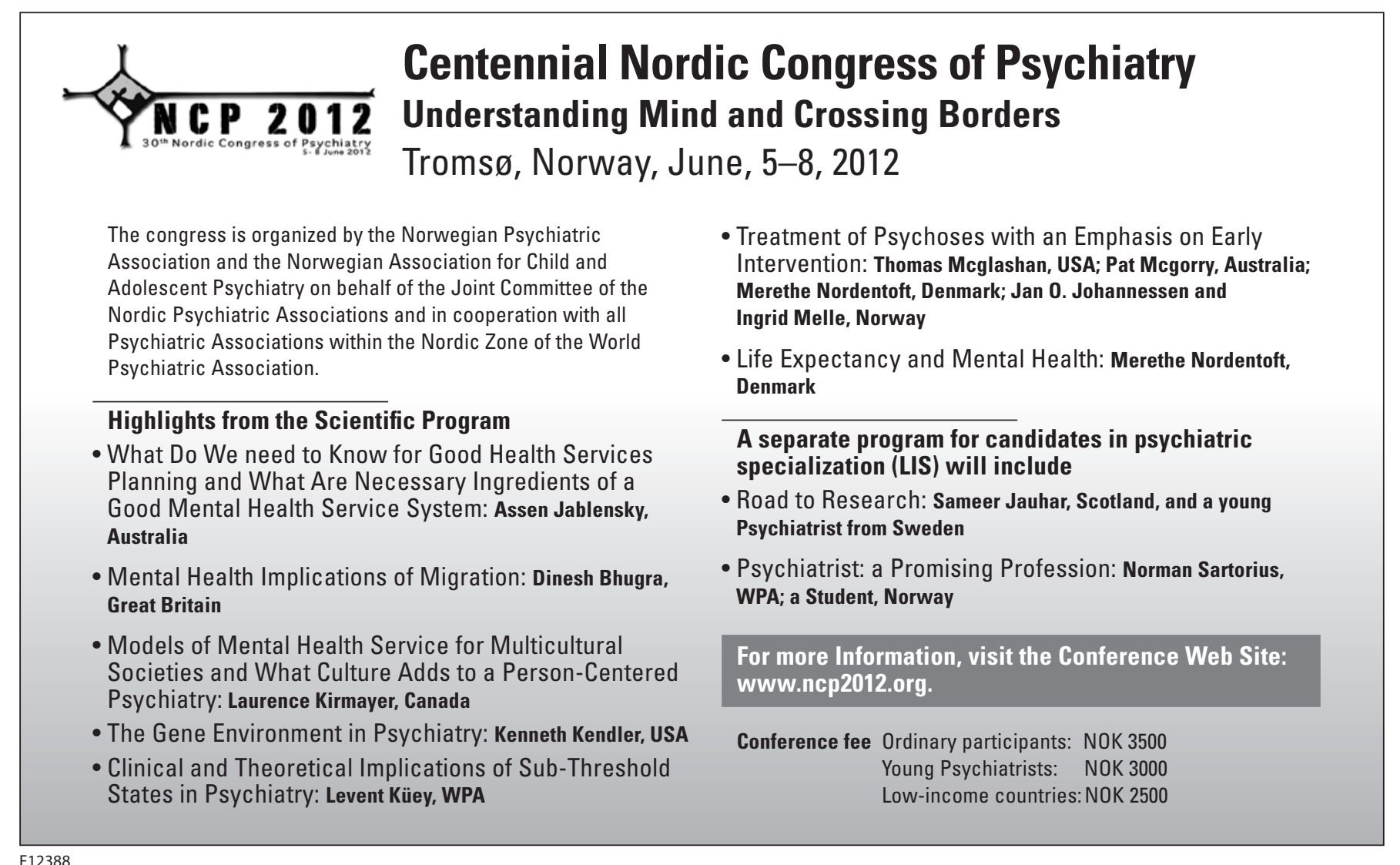

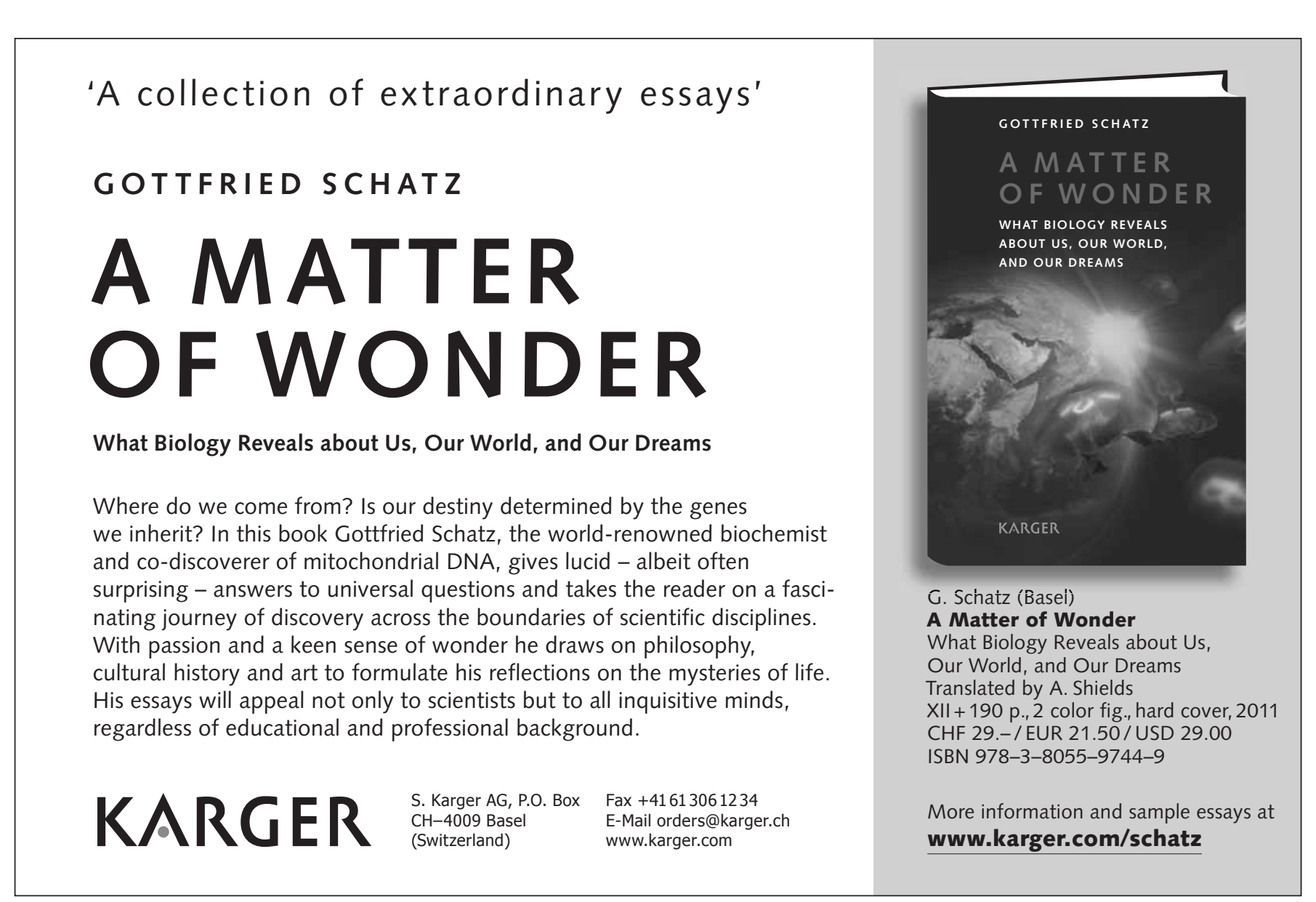




\section{Contents}

See the journal website for contents

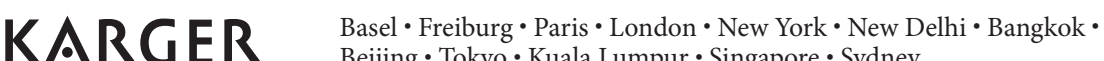
Beijing $\cdot$ Tokyo $\cdot$ Kuala Lumpur $\cdot$ Singapore $\cdot$ Sydney 


\section{Announcement of a Prize Essay}

Invitation to trainees

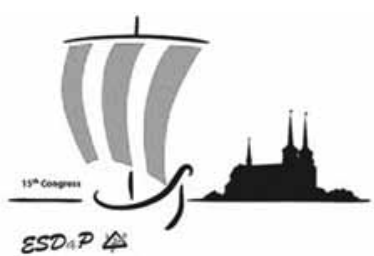

\section{Propose investigations in a psychodermatological topic and Give a 15 Minutes Lecture on the Results}

\section{At the 15th Congress of the European Society for Dermatology and Psychiatry in Roskilde, Denmark, 6th-8th June 2013 \\ Proposal due: 15 February 2012}

The 15th Congress of the European Society for Dermatology and Psychiatry (ESDaP) will take A STRUCTURED PERSPECTIVE on six psychodermatological topics:

- Body Dysmorphic Disorder

- Self-induced skin-lesions

- Pharmacology

- Psychoneuroimmunology

- Therapy - Mindfulness, Cognitive Therapy,

Psychodynamics/ Psychoanalyses

- Stigmatization

\section{The Structured Perspective}

Standardised structure of each symposium total $2 \mathrm{~h}$

\section{Idea}

Introduction and background - specific topic of psychodermatological relevance

Senior researcher

1 lecture of 30 minutes

\section{Methods}

How to get scientific results?

Senior researchers

2 lectures of 20 minutes

\section{Data}

Results of announced investigations, with only brief reference to background

Junior researchers

3 lectures of 15 minutes

The aim of the structured perspective is to increase the knowledge, provide data and improve the medical/therapeutic care in relation to the topic. It is hoped that this will be obtained by an in depth understanding of a chosen topic facilitated by the structured approach:

1. What is covered by the subheading of a given topic (background, problematic, perspective etc.)?

2. How can scientific results be obtained (an overview of methods)?

3. What do a variety of scientific methods show (methods and results)?

\section{The Prize Essay}

The Prize Essay refers to the third part of the structured perspective: Data.

The aim of the competition is to promote investigations that will provide hard scientific data on the chosen subjects.

Applicants are invited to submit research protocols for any of the six topics of the 15th ESDaP congress. The proposal shall include a detailed plan of the study: objectives, hypothesis, study goals, research questions, materials and methods (study setting, study design, sampling frame, sample size, variables), and provisional references.

The winners of the prize essay will enter into the main programme with a 15 minutes lecture at the forthcoming congress in Roskilde, Denmark, June 6th-8th 2013 and describe the project in an article by the end of 2013.

In addition to a place in the invited programme of the congress, the winners will receive a free membership of ESDaP for 1 year, and free congress registration for the presenting author.

Abstract due: 1st April 2013
Applicants' position

Trainee applicants will be preferred.

Proposal Evaluation and Selection Procedures The local organizing committee will perform the evaluation of the proposals and the selection made on the basis of scientific merit, relevance and data content of each proposal.

\section{Submission of proposal \\ Submission of proposals to ses@regionsjaelland.dk}

\section{Questions and Contact}

Local Organizing Committee:

President of the Local Organizing

Committee, ESDaP

Gregor Jemec, Professor, MD, DMSc

Tel. +4547322600

gbj@regionsjaelland.dk

Vice-president of the Local Organizing

Committee, ESDaP

Solveig Esmann, MA

Tel. +45 47322670

ses@regionsjaelland.dk

Michael Heidenheim, MD

Tel. +45 473226000

mih@regionsjaelland.dk

Erik Simonsen, Professor, MD, Ph.D.

Tel. +45 4732 7775,

es@regionsjaelland.dk

Morten Birket-Smith, MD

Tel. 35316416

Morten.Birket-Smith@regionh.dk

Robert (Bobby) Zachariae, Professor, MSc, MDSci, Tel. +458716 5878

bzach@aarhus.rm.dk

For questions related to this announcement please contact:

MA Solveig Esmann

Tel. +45 4732 2670,

ses@regionsjaelland.dk

For all other questions and more information about the ESDaP 2013 Conference, please contact the

Conference Secretariat:

CAP Partner

Contact person: Hanne Kvalheim

Tel. +45 70200305

hk@cap-partner.eu

\section{Important dates}

Submission of draft proposals due:

15th February 2012

Notification of the prize winners:

1st March 2012

Submission of abstract to ESDaP Congress due: 1st April 2013

Submission of manuscript due:

1st November 2013 


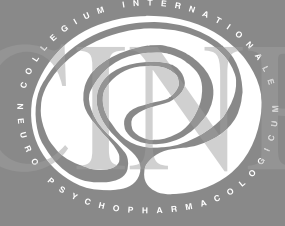

\section{8th CINP WORLD CONGRESS OF NEUROPSYCHOPHARMACOLOGY}

CINP - The International College of Neuropsychopharmacology

3-7 June 2012 है? Stockholm Sweden

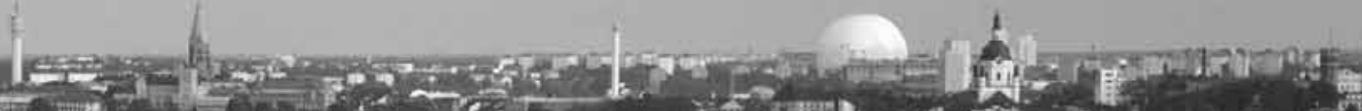

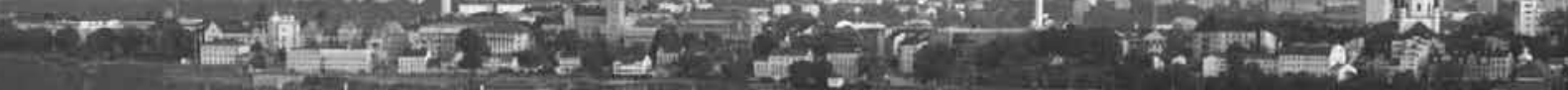

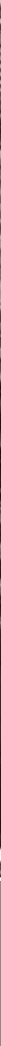




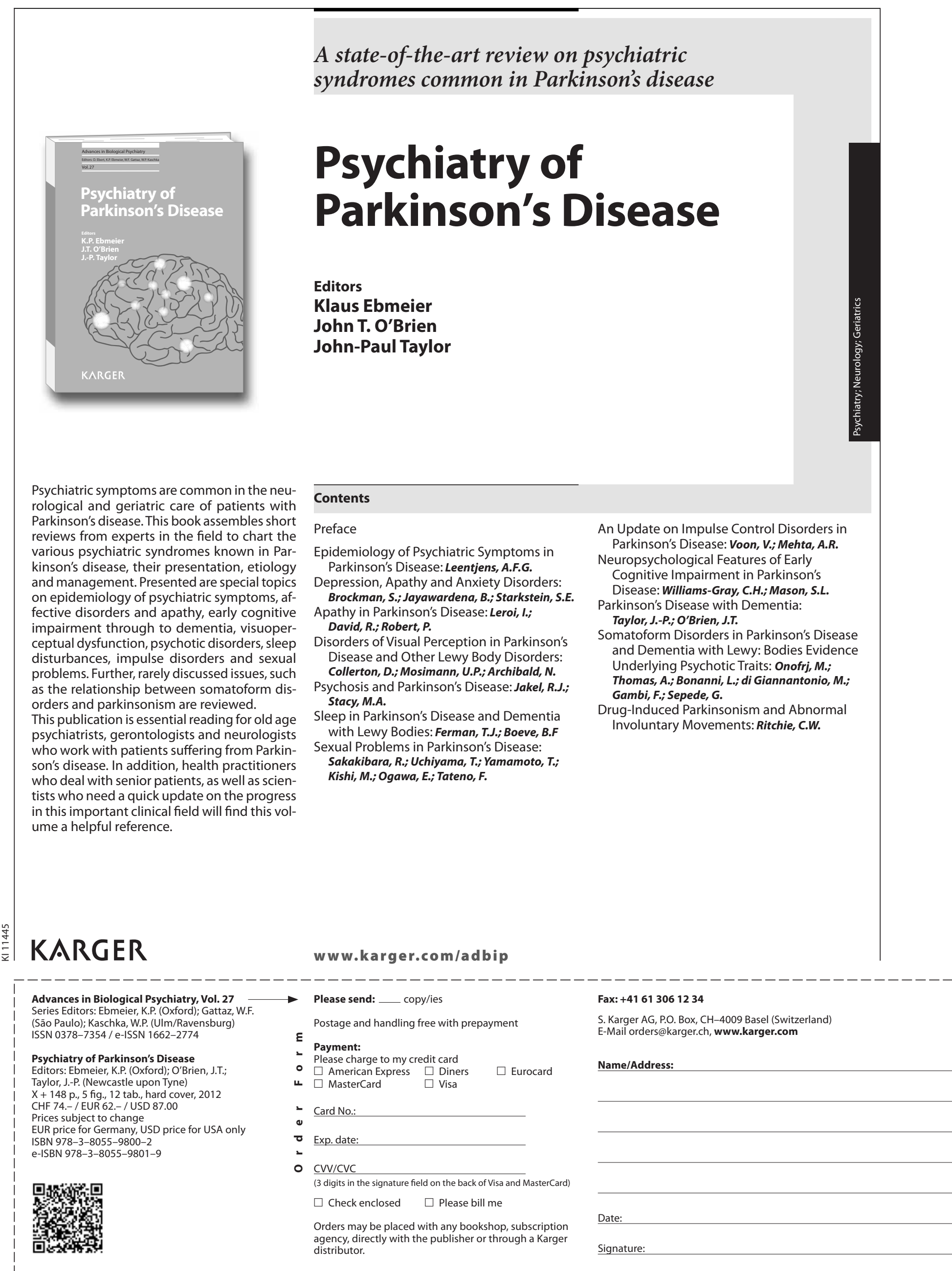




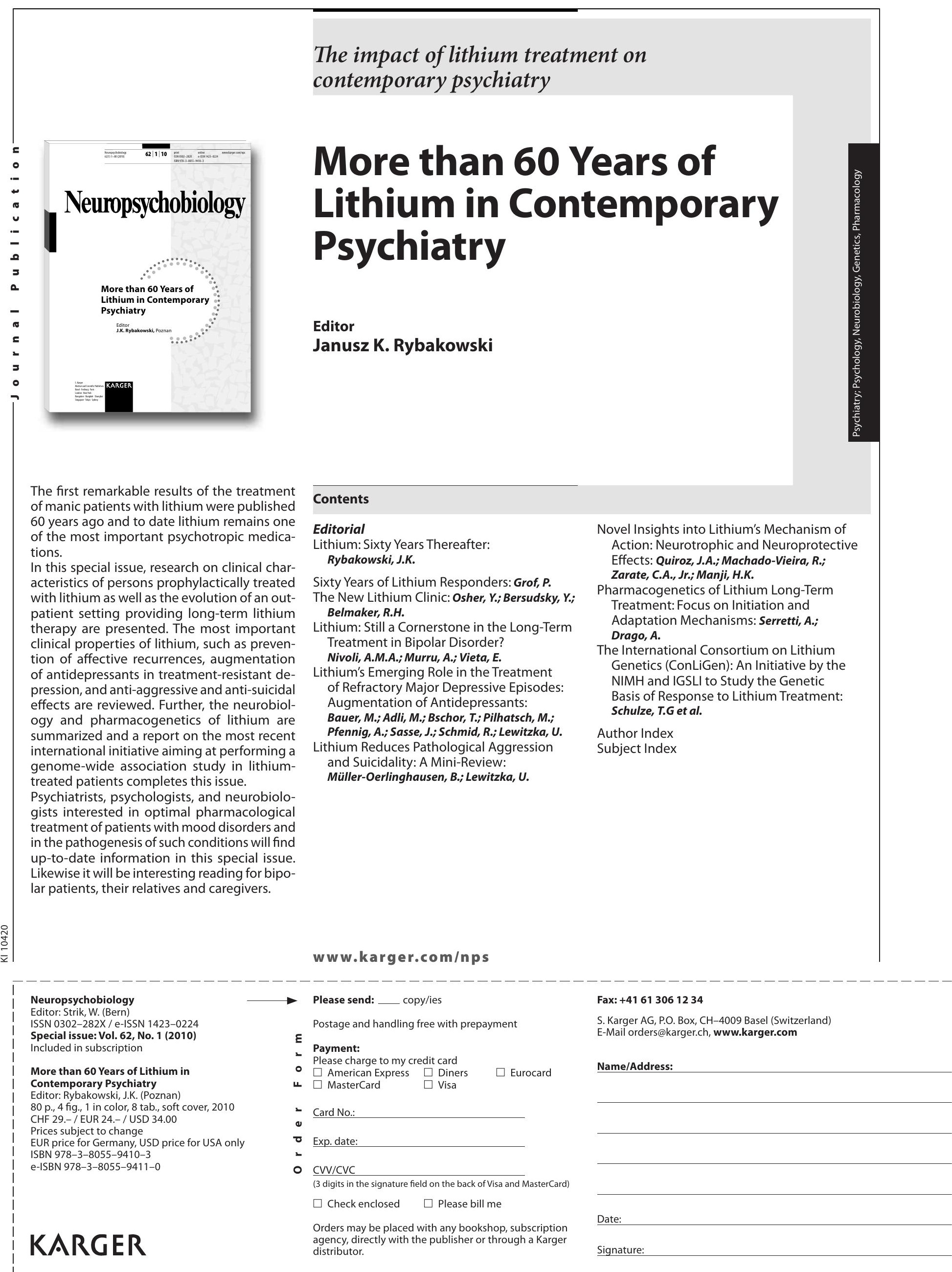




\title{
The Impact of Immigration on Children's Development
}

\author{
Editor \\ Cynthia Garcia Coll
}

All over the world families migrate, and with them so do their children. Probing the question of what 'being an immigrant' means, this publication brings together theory and empirical findings to highlight the impact of immigration on child development in a global context. Discussed is the impact of these processes on children and adolescents in a variety of different countries and social contexts to determine both universal and culturally specific aspects of the experience of immigration as it becomes a pervasive reality of the modern world.

This publication is appropriate for anyone who is interested in the process of migration/immigration and how it affects human development. Both students and scholars as well as real-world practitioners and policy makers in education, psychology, sociology, anthropology, ethnic and cultural studies, immigration studies, government and public policy will find this book a valuable source of information about the present and the way in which the next generation develops in response to the immigrant experience.

\section{Contents}

Introduction: The Global, the Local - Children and Immigration around the World: Garcia Coll, C.

Quiet in the Eye of the Beholder:Teacher Perceptions of Asian Immigrant Children: Yamamoto, Y.; Li, J.

The Impact of Social Contexts in Schools: Adolescents Who Are New to Canada and Their Sense of Belonging: Gagné, M.H.; Shapka, J.D.; Law, D.M.

Are Immigrant Children in Italy Better Adjusted than Mainstream Italian Children? Dimitrova, R.; Chasiotis, $A$.

Ethnic Identity, Acculturation Orientations, and Psychological Well-Being among Adolescents of Immigrant Background in Kenya: Abubakar, A.; van de Vijver, F.J.R.; Mazrui, L.; Arasa, J.; Murugami, M.

Immigrant Youth Adaptation in Context: The Role of Society of Settlement: Sam, D.L.; Horenczyk, $G$.
Examining Spiritual Capital and Acculturation across Ecological Systems: Developmental Implications for Children and Adolescents in Diverse Immigrant Families: Oh, S.S.; Yoshikawa, $\mathrm{H}$.

Immigrant Youth and Discrimination: Vedder, P.; van Geel, $M$.

Immigrant Family Separations: The Experience of Separated, Unaccompanied, and Reunited Youth and Families: Suárez-Orozco, C.; Hernández, M.G.

www.karger.com/cohde

Contributions to Human

Development, Vol. 24

Series Editor: Nucci, L. (Berkeley, Calif.)

ISSN 0301-4193

e-ISSN 1664-2570

The Impact of Immigration on

Children's Development

Editor: Garcia Coll, C. (Providence, R.I.)

$X+154$ p., 8 fig., 16 tab., soft cover, 2012

CHF 48.- / EUR 40.-/ USD 56.00

Prices subject to change

EUR price for Germany, USD price for USA only

ISBN 978-3-8055-9798-2

e-ISBN 978-3-8055-9799-9

E

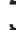

- Payment:

Please charge to my credit card

- $\square$ American Express $\square$ Diners

ᄂ $\square$ MasterCard $\square$ Visa

- Card No

ง

ర Exp. date

- $\mathrm{CVV} / \mathrm{CVC}$

( 3 digits in the signature field on the back of Visa and MasterCard)

$\square$ Check enclosed $\quad \square$ Please bill me

Orders may be placed with any bookshop, subscription agency, directly with the publisher or through a Karge distributor.

\section{Fax: +41613061234}

S. Karger AG, P.O. Box, CH-4009 Basel (Switzerland) E-Mail orders@karger.ch,www.karger.com

Name/Address: 


\section{Psychopathology}

Reviews

67 Anxiety Disorders through a Transcultural Perspective: Implications for Migrants Agorastos, A.; Haasen, C.; Huber, C.G. (Hamburg)

78 Neuropsychological Research in Delusional Disorder: A Comprehensive Review Ibanez-Casas, I.; Cervilla, J.A. (Granada)

Original Papers

96 Social Anxiety/Taijin-Kyofu Scale (SATS): Development and Psychometric Evaluation of a New Instrument

Asakura, S.; Inoue, T.; Kitagawa, N.; Hasegawa, M.; Fujii, Y.; Kako, Y.; Nakato, Y.; Hashimoto, N.; Ito, K.; Tanaka, T.; Nakagawa, S.; Kusumi, I.; Koyama, T. (Sapporo)

102 Syndromal and Subsyndromal Illness Status and Five-Year Morbidity Using Criteria of the International Society for Bipolar Disorders Compared to Alternative Criteria De Dios, C.; Agud, J.L.; Ezquiaga, E.; García-López, A.; Soler, B. (Madrid); Vieta, E. (Barcelona)

109 Comparison of Self- and Clinician's Ratings of Personal and Social Performance in Patients with Schizophrenia: The Role of Insight

Schaub, D.; Brüne, M.; Bierhoff, H.-W.; Juckel, G. (Bochum)

117 The Influence of Social Cognition on Ego Disturbances in Patients with Schizophrenia

Schimansky, J.; Rössler, W.; Haker, H. (Zurich)

Case Report

126 Concurrent Koro and Cotard Syndromes in a Spanish Male Patient with a Psychotic Depression and Cerebrovascular Disease

Alvarez, P.; Puente, V.M.; Blasco, M.J.; Salgado, P.; Merino, A.; Bulbena, A. (Barcelona)

Letters to the Editor

130 Cognitive Inhibition and Shifting in Asperger's Syndrome

Cui, J.; Chen, Y.; Zhang, X.; Wang, Y. (Beijing); Gao, D.; Zou, X. (Guangzhou)

133 The Origin of the Concept of Psychosis: Canstatt 1841

Bürgy, M. (Stuttgart) 